\title{
Real or Virtual Laboratories in Science Teaching - is this Actually a Dilemma?
}

\author{
Slavko KOCIJANCIC \\ University of Ljubljana, Faculty of Education \\ Kardejeva pl. 16, SI-1000 Ljubljana, Slovenia \\ e-mail:slavko.kocijancic@pef.uni-lj.si \\ Colm O'SULLIVAN \\ National University of Ireland, Department of Physics \\ Cork, IE-Cork, Ireland \\ e-mail: ctosull@ucc.ie
}

Received: August 2004

\begin{abstract}
Considerable pedagogical advantage may be gained by the integration of the different ICT tools commonly used in teaching science and technology, particularly by integrating "real" and "virtual" laboratory activities. In the context of this paper, "real" laboratories involve benchtop experiments utilizing data acquisition systems while "virtual" laboratories entail interactive simulations and animations. Examples of such integrated activities are described; namely, (i) the study of wave phenomena using sound and (ii) a study of motion in one dimension. Such integrated computerized teaching tools also provide an opportunity for a greater level of integration of different science and technology disciplines.
\end{abstract}

Key words: data acquisition, computerized experiments, technology teaching, physics education, integrated science.

\section{Introduction}

Classroom use of Information and Communication Technology (ICT) for teaching science and technology has increased dramatically in recent years and has proved to be a very effective tool in a variety of situations (Newton, 1997; Rogers, 1997; Sassi, 2000; Rogers and Wild, 1994; Kocijancic and Jamsek, 2004). The most commonly employed pedagogical uses of ICT fall into two apparently distinct categories which may be classified, respectively, as "virtual laboratory" and "real laboratory" applications. In a "virtual laboratory" computers are used, for example, to simulate or animate specific scientific phenomena; pupils normally engage in hands-on activities which are directed towards increasing their understanding and insight of the principles involved. Computer utilities may also be used to simulate complicated, expensive and/or inaccessible devices (for example, a nuclear reactor) or to replace environmentally hazardous laboratory experiments. Such educational materials are often integrated within interactive html documents for web-based learning. 
The importance of traditional laboratory teaching involving practical experimentation and hands-on work ("real laboratory"), however, has in no way decreased as a result of the use of computerized simulation experiments. If anything, computers equipped with data acquisition and control systems have had the effect of increasing the level of hands-on experimental activity in science laboratories at both high school and university. Supported by a variety of sensors and actuators, these systems have been shown to be pedagogically effective, particularly where higher level learning skills are concerned. Computerized experiments tend to change the emphasis from routine, often tedious, data collection towards interpreting skills, enhanced scientific thinking, creativity and problem solving (Barton and Rogers, 1991).

We believe that there is considerable additional pedagogical advantage to be gained by the integration of the various ICT tools and concepts available, particularly by integrating "real" and "virtual" laboratory activities. In addition, ICT based teaching tools provide an opportunity for a greater level of integration of different science and technology disciplines than heretofore. In either context, however, it is important that methodologies adopted be chosen appropriately to the specific learning goals and age of the students involved.

For this purpose novel state-of-the-art hardware, software tools and courseware are under development by the ComLab-SciTech project (for details see the project website http://e-prolab.com/comlab). The study of sound as a wave phenomenon and the study of one-dimensional motion are outlined below as examples of topics lending themselves to the integration of data acquisition experiments and simulations.

The experiments and software described in the paper were developed under the EU programme Leonardo da Vinci II within the pilot project Computerised laboratory in science and technology teaching. The software can be downloaded free of charge from the project website.

\section{Wave Phenomena in Sound}

We first describe a set of computer based experiments and related computer simulations directed towards the study of sound which were prepared for pupils at secondary school level in Slovenia.

\subsection{Speed of Sound}

An initial discussion with the pupils on the nature of sound usually progresses to a debate about of its speed of propagation. Students describe some of their own experiences from which they conclude that the detection of a sound signal is delayed with respect to its emission. Pupils raise many well known examples of such phenomena, such as the delay between lightning and the subsequent sound of thunder or echoes resulting from reflection of sound from a wall or cliff. After this discussion, a simple experiment is introduced using standard laboratory data acquisition (DAQ) apparatus (see Fig. 1). The analogue output of the system is being used in order to turn on the sound emission of the DC 

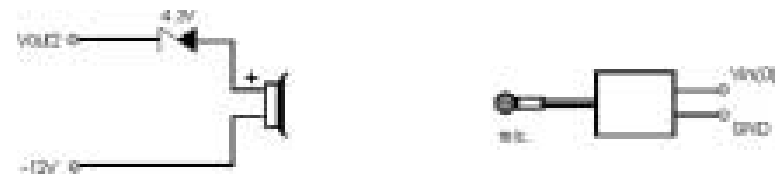

Fig. 1. Experimental arrangement for determining the speed of sound

supplied piezoelectric loudspeaker by changing the output voltage from $-10 \mathrm{~V}$ up to +10 $\mathrm{V}$. The function of the Zener diode is to prevent the sound emission when voltage on Vout2 is $-10 \mathrm{~V}$. A microphone is placed up to three metres from the loudspeaker and the amplified signal from the microphone is connected to the analog input. The signal from the microphone is sampled immediately after the loudspeaker has been turned on. A software package (called e-ProLab) enables the generation of the output signal to the loudspeaker as well as graphical display of the captured data from the microphone in a manner of a computer based oscilloscope.

The distance between the loudspeaker and the microphone can be varied and the corresponding time delay determined (see Fig. 2). By using piezoelectric loudspeakers emitting sound of different frequencies, the time delay for a fixed loudspeaker-microphone distance can be measured for each frequency.

The results of the experiment lead pupils to form the following conclusions:

- The time delay is proportional to distance; furthermore, speed of sound is about $340 \mathrm{~m} / \mathrm{s}$.

- The speed of sound does not depend on frequency of the sound.

- The amplitude of the sound decreases with distance from the source.

At this point, the term of wavelength is introduced by the teacher as general wave concept, not specific to sound waves. The wavelength of sound cannot be observed directly, so the relationship between the speed, wavelength and frequency can be best visualized via a computer simulation. The animated simulation used for this purpose is a PC

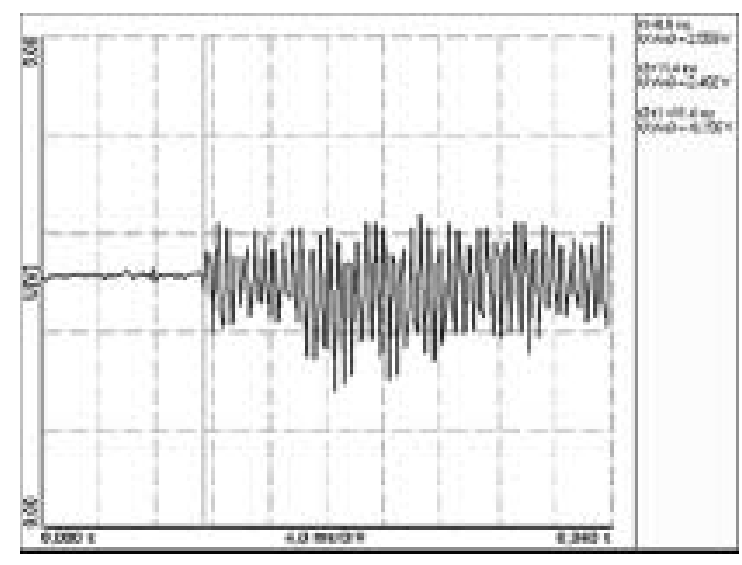

Fig. 2. The signal detected by a microphone at $3.2 \mathrm{~m}$ from a loudspeaker. 

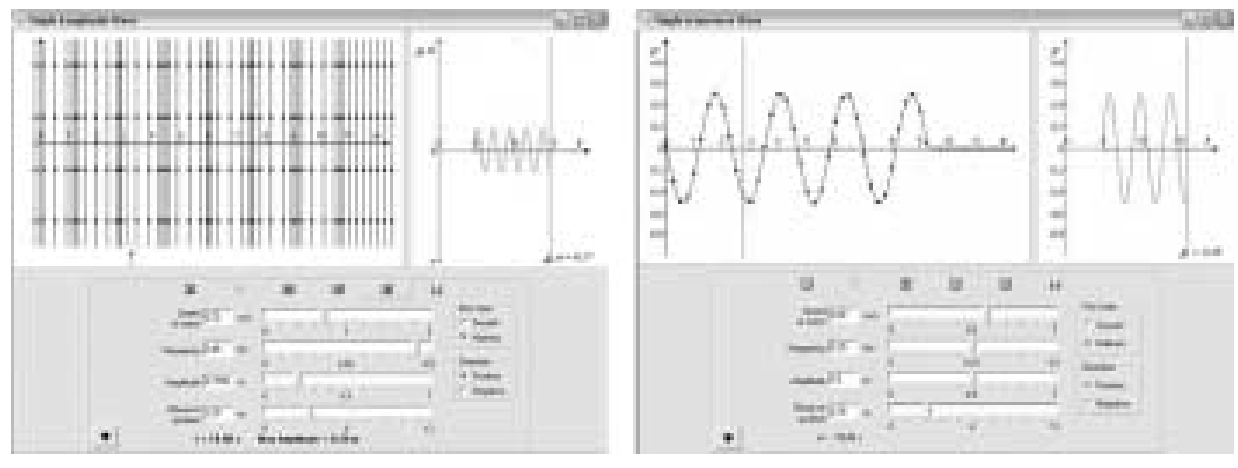

Fig. 3. Computer screen during the simulation of wave propagation; longitudinal wave on left and transverse wave on right.

Windows based application developed and designed in co-operation with the XLab Ltd., Slovenia (http: / / www . xlab.si)

The simulation enables two parameters, the speed and the frequency of waves, to be varied while wavelength is seen to depend on both $(\lambda=c / f)$. Two charts are presented on screen (see Fig. 3): (i) the variation of the disturbance from equilibrium as a function of distance from the source of the waves and (ii) the time dependence of this disturbance at fixed distance, chosen by the user, from the source. The simulations, specifically developed to explain the phenomena, illustrate both longitudinal wave propagation (for sound) as well as transverse wave propagation.

\subsection{Superposition of Sound Waves}

In many everyday situations sound is emitted simultaneously from a number of sources. Pupils are asked to consider what kind of signal would be obtained at the microphone if two or more sources emit tones at different frequencies? An experiment may then be performed using two sound sources emitting predominantly sine tones of different frequencies ( $f_{1}$ and $f_{2}$, see Fig. 4). A number of different source pairs are possible, for example two membrane loudspeakers each connected to a sine voltage generator, two or more tuning forks, chime bars, different DC piezoelectric loudspeakers at different distances (to influence the amplitude of each signal), etc.
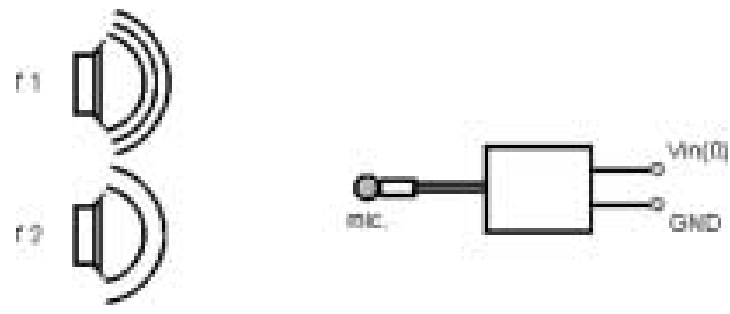

Fig. 4. Experimental arrangement for the study of interference of sound. 
The signal from the microphone is initially observed with only one source emitting sound, then with the second sound source alone and finally with both sound sources emitting simultaneously (an example signal is shown in Fig. 4). At this point, the Fast Fourier transform utility of the HiScope software is introduced (Fig. 5) in an empirical fashion, that is with emphasis on what it does without consideration of its mathematical foundation.

The concept of superposition of waves is then clarified with a computer simulation in which the user can combine of up to ten sinusoidal waves. All have the same speed of propagation while the frequency, amplitude and phase of the waves with respect to the first wave can be varied. An example of such superposition of the two waves is shown in Fig. 6.

Students are made aware that superposition of two or more sinusoidal sound emitters

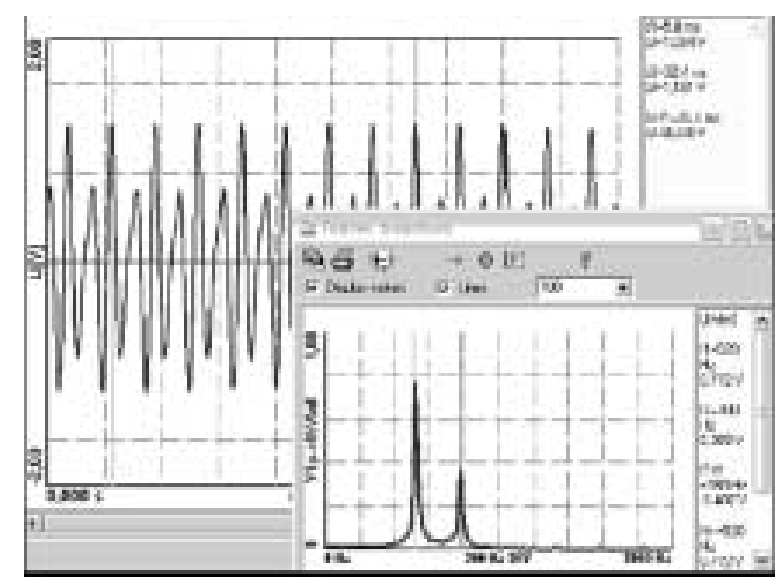

Fig. 5. Sample of signal from microphone obtained with two chime bars $\left(f_{1}=784 \mathrm{~Hz}, f_{2}=520 \mathrm{~Hz}\right)$.

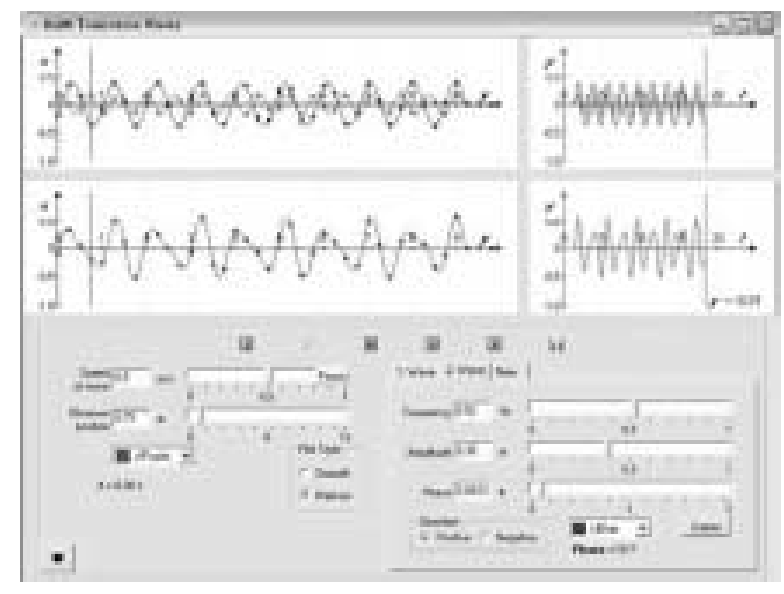

Fig. 6. Simulation of superposition of two waves. 


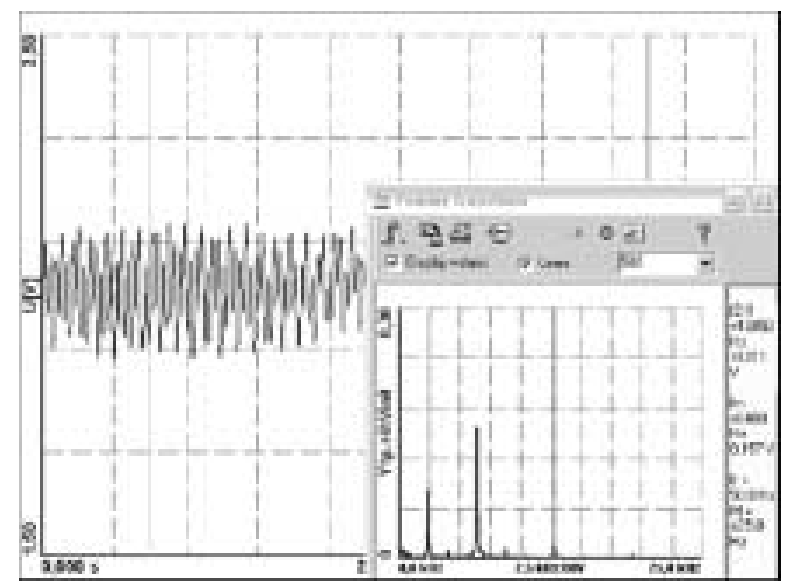

Fig. 7. Example signal obtained with a nail.

is not the only way to obtain a non-sinusoidal signal at the microphone. Experimentally it can be shown, that signal obtained for human vowel sounds or mechanical sound sources such as nails are periodic but not sinusoidal (Fig. 7). Again, observation of the Fourier transform of the digitized input signal can be used to illustrate that single sound sources can generate "superimposed" sound.

\subsection{Interference of Ultrasound}

Waves from two coherent ultrasound sources superimpose at different points of the space depending on the phase difference between both waves. Students learn that if the phase difference at a certain point is $n 2 \pi, n=0,1,2, \ldots$ the amplitude of the superimposed wave is the sum of the two amplitudes and, on the contrary, if the phase difference is $(2 n+1) \pi / 2, n=0,1,2, \ldots$, then the superimposed amplitude is the difference of the amplitudes.

Two ultrasonic emitters are placed at a fixed, but variable, distance apart in a horizontal plane, directed upwards and connected to a $40 \mathrm{kHz}$ voltage generator in order to provide two adjacent sources of coherent ultrasonic waves. A stick that can be rotated at one end around an axis in the plane has a receiver mounted at the other end connected to an amplifier (Fig. 8).

The amplified signal from the receiver is connected to the analogue input of the DAQ system and its amplitude is observed at different positions of the receiver. Maximum and minimum sound wave amplitude is observed at different angles of the stick (Fig. 9 left).

The interference of two coherent transverse waves is then illustrated by a computer simulation in which the user can vary the same parameters as in the real experiment (see Fig. 9 right). 


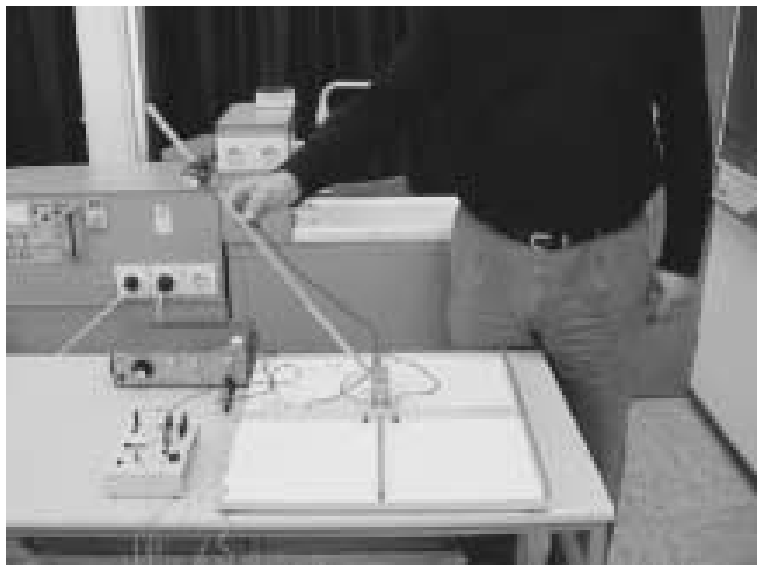

Fig. 8. Photograph of the experiment apparatus for the study of interference of ultrasound.
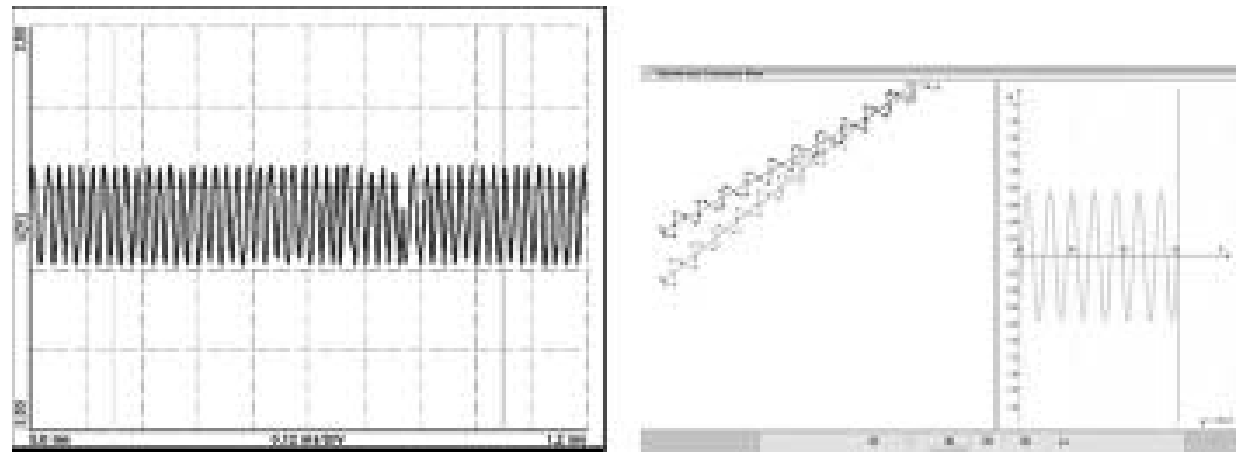

Fig. 9. Example of the signal obtained from the ultrasound receiver (left) and corresponding virtual experiment (right).

\section{One Dimensional Motion}

The problem of student difficulties in connecting graphs to physical reality is well known (McDermott et al., 1987) as is the value of laboratory experiments using real-time computerised data acquisition with graphical display to address these problems (Newton, 1997; Rogers, 1997). The ultrasound distance sensor has proved to be a particularly valuable tool in this context as described, for example, by Sassi (2000). The study of motion, therefore, is a topic where numerous real experiments can be complemented with computer simulations.

\subsection{Motion of a Cart on an Incline}

Fig. 10 shows a simple and commonly used example of one dimensional motion in which the motion of a cart moving with constant acceleration is studied by observing a real time plot of distance versus time. In the particular case illustrated, the cart was given an 
upward push at the bottom of the incline. A position versus time curve is plotted of the data sampled by the ultrasonic sensor. The data is used for calculating the velocity. The data acquisition software displays the curves simultaneously with the motion of the cart. After performing the experiment, secondary school pupils generally have no problems in answering elementary questions with reference to the plots, such as

- At what time interval the cart moved upwards and when downwards?

- At which moment the cart reached the maximum displacement and what was it?

- When does the cart change its direction of motion?

Pupils find it less easy to give answers to some other questions:

- For the particular motion, which direction is defined as positive - upwards or downwards?

- Over what time interval was the velocity positive and when was it negative?

- Over what time interval was the acceleration positive and when it was negative?

- Is it possible that the velocity of the body at a given position is zero but its acceleration is not zero?

- Can the direction of motion change but the acceleration remain the same?

After clarifying the interpretation of the graphs, pupils are asked to make some further analyses of the sampled data - say what was the acceleration during the upwards motion and what was it when moving downwards. Note that acceleration obtained is different in each of these cases because of the effect of the force of friction, as can be seen in Fig. 10.

A corresponding simulation enables animation of the motion as well as simultaneous graph plots of position, velocity and acceleration. Pupils are asked to set the variable parameters (initial position, velocity and acceleration) to obtain a similar motion as observed in the real experiment (see Fig. 11).

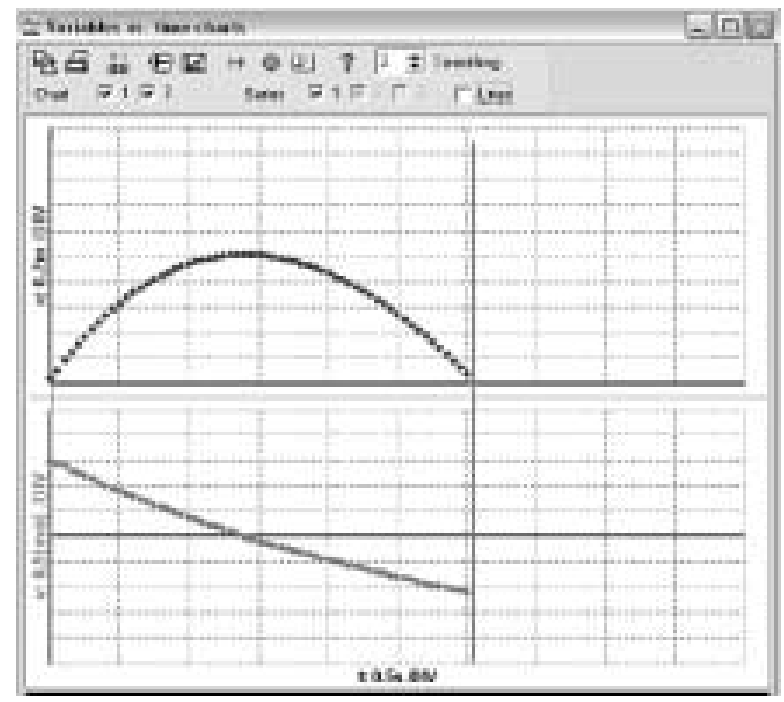

Fig. 10. Real experiment: position and velocity curves obtained during motion up and down an incline. 


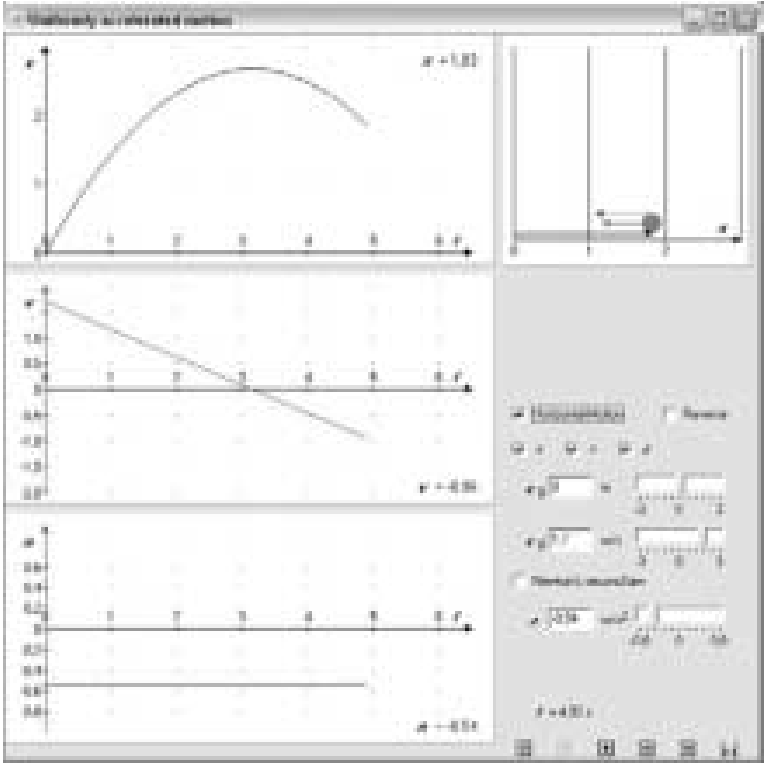

Fig. 11. Virtual experiment: simulation of upward and downward motion showing position, velocity and acceleration curves.

\subsection{Oscillatory Motion}

The methodology of the integration of real and virtual experiments to study oscillatory motion is similar as in previous example. Experimental data obtained with a spring oscillator as well as corresponding virtual experiment are shown in Fig. 12.
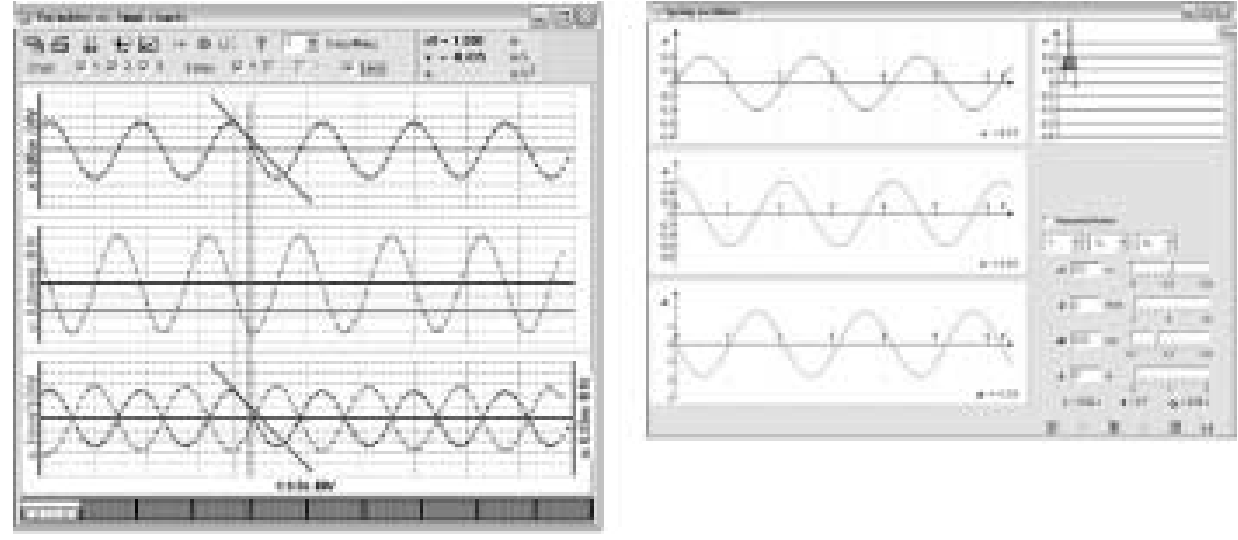

Fig. 12. Oscillatory motion: real experimental data (left) and virtual experiment (right). 


\section{Conclusions}

The integration of data acquisition experiments with closely associated computer simulations has proved to be particularly effective in the learning process. It can be concluded that it is not a question whether it is better to use real experiments or virtual laboratory in science teaching as both approaches used in a complementary way can contribute to more effective active learning.

\section{Acknowledgements}

Support received under the EU Leonardo da Vinci Community Vocational Training Action Programme, project SI-143008 Computerised Laboratory in Science and Technology Teaching (ComLab-SciTech), is gratefully acknowledged.

\section{References}

Newton, L. (1997). Graph talk: some observations and reflections on students' data-logging. School Science Review, 79, 49-54.

Rogers, L. (1997). New data-logging tools - new investigations. School Science Review, 79, 61-68.

Sassi, E. (2000). Computer supported lab-work in physics education: advantages and problems, International Conference on Physics Teacher Education beyond 2000, Barcelona (cdrom).

Rogers, L. T., and J. Wild (1994). The use of IT in practical science - a practical study in three schools. School Science Review, 75, 273, 21-28.

Kocijancic, S., and J. Jamsek (2004). Electronics courses for science and technology teachers. Int. J. Eng. Educ., 20, 244-250.

Barton, R., and L.T. Rogers (1991). The computer as an aid to practical work - studying motion with a detector. Journal of Computer Learning, 7, 104-112.

McDermott, L.C., M.L. Rosenquist and E.H. van Zee (1987). Student difficulties in connecting graphs and physics: examples from kinematics. American Journal of Physics, 55 (6), 503-513. 
S. Kocijancic has a $\mathrm{PhD}$ in electrical engineering. He taught physics at high school level from 1982 until 1989. Since then he has lectured in electronics at the Faculty of Education, University of Ljubljana, Slovenia. Since 1985 he has been involved in design and development of instrumentation and software for computer based science laboratories in schools and universities.

C. O'Sullivan has a PhD in astrophysics. He has lectured in the Department of Physics, National University of Ireland, Cork since 1970. During this time his research interests have involved cosmic ray astrophysics and physics education. 


\section{Realiu ir imituotu laboratoriju taikymas mokymo procese: ar tai tikrai dilema?}

\section{Slavko KOCIJANCIC, Colm O’SULLIVAN}

Nemažu pedagoginių laimèjimų galima pasiekti pasitelkus skirtingu informaciniu ir komunikaciniu priemoniu, paprastai naudojamu mokant ir taikomų technologijose, derini. Šiuo atveju ypatingą reikšmę igyja realių ir virtualiu laboratorijų taikymas. Čia pateikiamo straipsnio kontekste realiomis laboratorijomis vadinamos tos, kuriose eksperimentai atliekami tiesiogiai naudojantis iprastomis priemonemis, kitaip tariant "ant stalo", pasitelkus icvairias duomenu rinkimo priemones. Virtualiosiomis laikomos tos, kuriose taikomos interaktyvios simuliacijos bei naudojama animacija. Straipsnyje iš esmès supažindinama su dvejopa integruota veikla: 1) garso bangu fenomeno studijos, 2) vienmatis judejimo tyrimas. Tokios integruotos kompiuterinès mokymo priemonès yra svarbios ir užtikrina kokybiškesni skirtingų mokslų ir technologinių disciplinų integravimo lygi. 